\begin{tabular}{l} 
JOURNAL OF EMPOWERMENT \\
VOL. 2., No. 2, Desember 2021, h. 183-192 \\
ISSN 2580-0620 (Print) \\
ISSN 2597-9809 (Online) \\
Available Online at https://jurnal.unsur.ac.id/index.php/JE \\
\hline \hline
\end{tabular}

\title{
PEMBERDAYAAN MASYARAKAT MELALUI PLANT GROWTH PROMOTING RHIZOBACTERIA BERBAHAN DASAR AKAR BAMBU
}

\section{COMMUNITY EMPOWERMENT THROUGH PLANT GROWTH PROMOTING RHIZOBACTERIA BASIC BAMBOO ROOTS}

\author{
Adnan', Zulkarnen Mora², Syardiansah ${ }^{3}$ \\ 123Universitas Samudra \\ adnan@unsam.ac.id, zulkarnen.mora@unsam.ac.id, syardiansah@unsam.ac.id
}

Masuk: 16 Agustus $2021 \quad$ Penerimaan: 04 Desember 2021 Publikasi: 31 Desember 2021

\begin{abstract}
ABSTRAK
Pupuk merupakan salah satu yang sangat dibutuhkan tanaman, oleh karena itu ketersediaan nya didalam masyarakat khususnya dipedesaan sangat diharapkan. Harga pupuk buatan (pabrikan) yang terlalu tinggi saat ini sangat sulit untuk mendapatkan sehingga untuk keperluan budidaya tanaman baik padi, palawija dan sayur-sayuran sangat terbatas. Terkait dengan kondisi tersebut maka masalah kekurangan pupuk dan hara tanaman menarik untuk ditelaah dan dikaji, guna dapat dicari solusi nya. Salah satu alternative untuk mengatasi kekurangan pupuk dan ketersediaan hara bagi kebutuhan dalam budidaya pertanian maka dapat diatasi dengan pemanfaatan sumber daya lokal yang ada di desa yaitu dengan membuat pupuk Organik Cair Plant Growth Promoting Rizobacteria (PGPR) yang berfungsi merangsang pertumbuhan dan mempercepat proses dekomposisi, pengurangan pestisida dan rotasi penanaman dapat mendorong pertumbuhan populasi dari bakteri yang menguntungkan.
\end{abstract}

Kata Kunci : Akar bambu, Plant Growth Promoting Rizobacteria

\begin{abstract}
Fertilizer is one that is needed by plants, therefore its availability in the community, especially in rural areas is expected. The price of artificial fertilizers (factory) which is currently too high is very difficult to obtain so that the cultivation of crops such as rice, secondary crops and vegetables is very limited. In connection with these conditions, the problem of lack of fertilizers and plant nutrients is interesting to study and study, in order to find a solution. One alternative to overcome the shortage of fertilizers and the availability of nutrients for agricultural cultivation needs can be overcome by utilizing local resources in the village, namely by making Liquid Organic Fertilizer Plant Growth Promoting Rizobacteria (PGPR) which functions to stimulate growth and accelerate the process of decomposition, reduction. pesticides and crop rotation can promote population growth of beneficial bacteria.
\end{abstract}

Keywords : Bamboo roots Plant Growth Promoting Rizobacteria

\section{A. PENDAHULUAN}

Plant Growth Promoting Rhizobacteria, kalau diterjemahkan artinya kurang lebih: Rizobakteri Pemacu Pertumbuhan Tanaman, telah menjadi sesuatu yang sangat penting di seluruh dunia dan diakui menjadi sesuatu yang sangat menguntungkan bagi dunia pertanian. PGPR dapat menjadi salah satu solusi ketergantungan 
terhadap produk pupuk kimia sintetis, sehingga dapat menjaga pertumbuhan pertanian secara berkesinambungan dan mendukung visi secara global mengenai pembangunan, perlindungan dan pelestarian lingkungan yang sudah terlanjur rusak oleh aplikasi pupuk kimia sintetis. Riset ilmiah yang melibatkan berbagai disiplin ilmu terus menerus dilakukan untuk lebih memahami penerapan PGPR, efek terhadap fisiologi dan pertumbuhan tanaman, mekanisme PGPR dalam menginduksi dan membantu sistem ketahanan tanaman terhadap penyakit, fungsi PGPR sebagai biokontrol terhadap patogen yang merugikan tanaman, sebagai pupuk organik, dan menjadi alternatif alami untuk peningkatan produksi, pembentukan koloni rizosfera pada akar tanaman dan masih banyak lagi tujuan penelitian lainnya.

Ketersediaan Bahan Baku yang melimpah seperti halnya akar bambu untuk pembuatan Plant Growth Promoting Rhizobacteria (PGPR) yang berfungsi memacu proses pertumbuhan tanaman, merupakan peluang dalam usaha pertanian, karena ketersediaan pupuk selalu menjadi masalah dalam dalam upaya peningkatan produksi. Terbatasnya pengetahuan masyarakat terhadap pengelolaan potensi lokal yang tersedia di Gampong Sarah Teubee Kecamatan Rantau Seulamat tidak bisa termanfaatkan dengan baik. Hal ini juga disebabkan oleh pengetahuan petani yang terbatas sehingga belum dapat memanfaatkan bahan baku yang tersedia di desanya sebagai bahan baku pembuatan Pupuk cair organik PGPR.

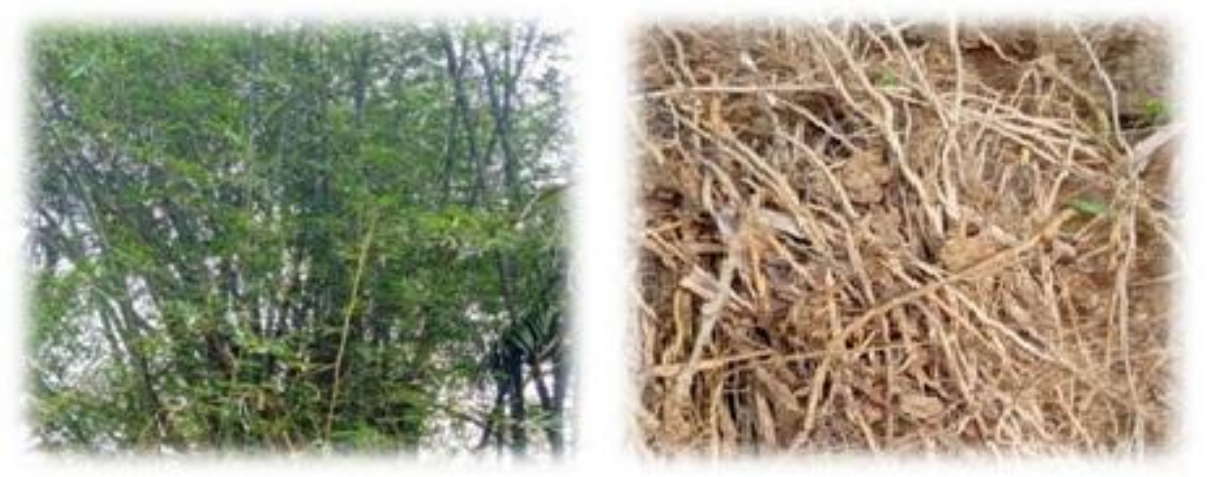

Gambar 1. Bahan Baku PGPR

Penggunaan mikroorganisme untuk tujuan meningkatkan penyerapan nutrisi tanaman adalah sesuatu yang sangat penting diketahui dalam pertanian organik (Freitas dkk, 2007). Selama beberapa dekade terakhir, pemanfaatan PGPR untuk pertanian ini telah meningkat di berbagai tempat.

Mengutip artikel dari Plant Growth Promoting Rhizobacteria : Fundamentals and Aplications by Marcia do Vale BF, et al, terdapat beberapa manfaat dari PGPR ini, di antaranya :

1. Meningkatkan nutrisi mineral terlarut dan pengikatan nitrogen, sehingga nutrisi dapat terserap oleh tanaman

2. Menekan pertumbuhan patogen dalam tanah, (dengan salah satunya menghasilkan Hidrogen Sianida dan antibiotik), berfungsi sebagai biokontrol terhadap serangan patogen yang terdapat dalam tanah

3. Meningkatkan daya tahan stress tanaman terhadap kekeringan, saliniti, dan racun-racun metal/logam

4. Menghasilkan fitohormon seperti indole-3-acetic acid (lebih dikenal dengan istilah (AA), auksin, sitokinin, dan giberelin 
Jadi secara garis besar, fungsi umum PGPR dalam meningkatkan pertumbuhan tanaman dibagi menjadi 3 bagian (Tenuta, 2006 ; Cattelan, et all, 1999, Kloepper, 1993)

1. Sebagai pemacu atau perangsang pertumbuhan (biostimulants) dengan mensintesis dan mengatur konsentrasi berbagai jenis zat pengatur tumbuh (fitohormon) seperti auksin, sitokinin, giberelin, dan etilen dalam lingkungan akar

2. Sebagai penyedia unsur hara (biofertilizers) dengan mengikat nitrogen dari udara secara asimbiosis dan melarutkan unsur hara $P$ yang terikat dalam tanah

3. Sebagai pengendali patogen yang berasal dari tanah (bioprotectans) dengan cara menghasilkan berbagai senyawa atau metabolit anti patogen

Gampong Sarah Teubee merupakan desa yang memiliki lahan sawah tadah hujan dengan luas lahannya yaitu 20 ha serta lahan lainnya yang luas keseluruhanya adalah 1.560,5 ha (sumber: Potensi Desa Sara Teubee:2019). Lahan ini memiliki potensi untuk pengembangan tanaman berbagai macam tanaman selain tanaman padi.
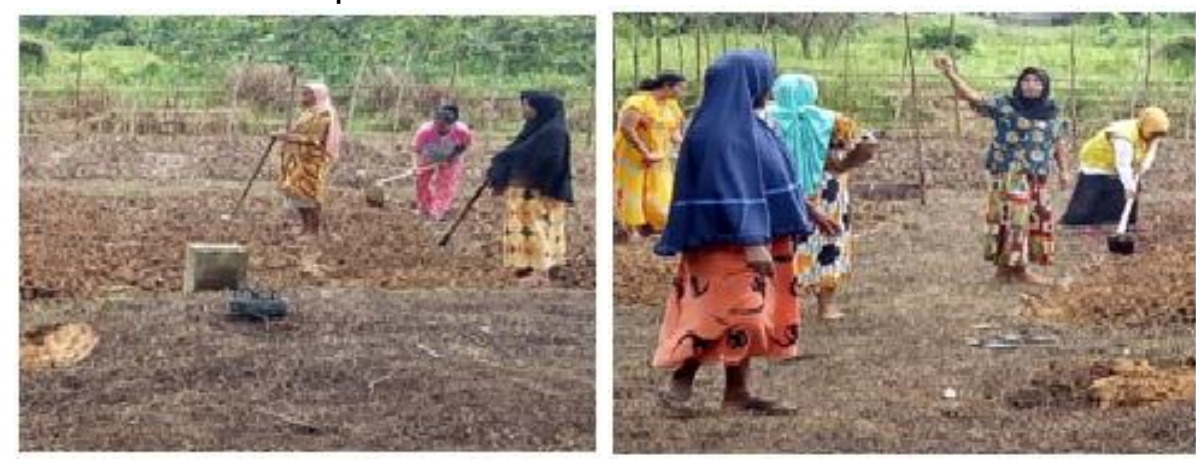

Gambar 2. Kegiatan Warga Desa Sarah Teubee

Selain itu petani di Gampong Sarah Teubee merupakan kelompok masyarakat tani yang sebagian besar tidak produktif secara ekonomi karena petani di Gampong tersebut hanya mampu melaksanakan budidaya padi pada lahan sawah tadah hujan atau lahan kering yang mereka miliki tanpa ada usaha pemanfaatan lahan dengan komoditi yang lain seperti Jagung dan sayur-sayuran. Dalam upaya menambah penghasilan masyarakat dan pengembangan usaha agribisnis perlu dilakukan identifikasi faktor internal dan eksternal dari sumberdaya lahan sawah dan lahan kering berpotensi untuk dikembangkan tanaman lain seperti sayuran, cabe dan kacang-kacangan. Peluang usaha budidaya tanaman tersebut memiliki prospek cerah dari waktu ke waktu, dengan masa panen yang pendek sehingga menjadi pilihan kelompok tani untuk berwirausaha agribisnis dengan keuntungan menjanjikan.

Kelompok masyarakat yang menjadi mitra dalam kegiatan Program Pengabdian kepada Masyarakat (PKM) ini adalah masyarakat yang tergabung dalam kelompok tani Wanita Tani "Putroe Tani" yang diketuai oleh Ibu Siti Hawa dengan beranggotakan sebanyak 20 orang. Kelompok tani sebagai bagian integral pembangunan pertanian memiliki peran dan fungsi penting dalam menggerakkan pembangunan pertanian di perdesaan.

Gampong Sarah Teubee adalah satu gampong yang ada dan memiliki potensi sumber daya lokal yang mana petaninya memiliki keinginan yang kuat untuk mulai membudidayakan tanaman padi, palawija dan sayur-sayuran baik di lahan sawah tadah hujan dan lahan kering maupun tegalan. Namun permasalahan saat 
ini adalah banyak petani yang khususnya tergabung dalam kelompok-kelompok tani belum mampu meningkatkan produktivitas panennya disebabkan oleh tingginya harga pupuk non organik yang tesedia di pasaran. Salah satu kelompok tani yang menghadapi masalah akan penyediaan pupuk tersebut adalah kelompok tani wanita "Putroe Tani."

$\mathrm{Di}$ sisi lain, pengetahuan kelompok ini akan penggunaan pupuk organik yang berasal dari Gampong ini, masih belum dapat dimanfaatkan dengan maksimal, seperti pupuk cair yang diproses dari bahan-bahan alami yang terdapat di Gampong ini yang terdiri dari tumbuh-tumbuhan seperti bambu. Bambu-bambu yang tumbuh rimbun ini ternyata memiliki khasiat yang berguna bagi pertumbuhan tanaman-tanaman lain dengan tujuan mendorong sekaligus mempercepat tumbuh tanaman dengan masa yang pendek. Akar-akar yang terdapat pada bambu tersebut memiliki keunggulan dan berpotensi kuat untuk menghasilkan pupuk cair melalui proses Plant Growth Promoting Rhizobacteria. Proses pembuatan PGPR ini tidaklah sulit jika para anggota kelompok tani mau menghasilkannya. Namun dikarenakan oleh keterbatasan pengetahuan dan pengalaman maka kelompok tani tersebut lebih cendrung menggunakan pupuk yang telah tersedia di pasar berupa pupuk jenis non organik yang kurang efesien jika dibandingkan dengan penghasilan mereka.

Berdasar hasil pengamatan yang sudah dilaksanakan tim pengabdian ke kelompok Wanita Tani "Putroe Tani" diketahui bahwa kelompok tani selama ini hanya memiliki kegiatan kelompok dibidang pertanian khususnya padi dan hanya sebagian kecil saja petani yang telah membudidayakan tanaman palawija dan sayuran hanya beberapa petani yang bersifat komersial. Kegiatan budidaya tanaman padi dan sayur-sayuran biasanya dilakukan dilahan kering, baik pada lahan sawah maupun pada tegalan. sebagian besar petani yang tergabung kedalam kelompok wanita tani tersebut bekerja sebagian besdar menjadi kuli pabrik arang, dan buruh tani pada perusahaan perkebunan.

Hasil diskusi bersama ketua kelompok tani dan beberapa petani yang tergabung dalam kelompok tani di Gampong Sarah Teubee menyatakan masih menggunakan pupuk yang berasal dari produksi pabrik (non organik) pada tanaman, baik padi, palawija maupun sayur-sayuran. Hal ini karena petani mengungkapkan bahwa sangat sulit membuat pupuk organik cair seperti PGPR ini yang berbahan dasar dari alam seperti akar bambu. Sebenarnya PGPR tidak terlalu sulit untuk dibuat dan sangat mudah diaplikasikan, dengan harapan petani lebih mandiri dan mampu meningkatkan produksi, ramah lingkungan dan berkelanjutan. Melatih petani agar mampu menyiapkan sendiri kebutahan akan PGPR jauh lebih menguntungkan dibandingkan dengan membeli pupuk dipasaran, hal ini karena teknologi dan cara pembuatan PGPR mudah dan murah, sementara manfaat nya luar biasa, Sehingga petani dapat menjadi sebagai agent of change disamping dapat meningkatkan taraf hidupnya, juga bermanfaat bagi masyarakat juga masyarakat lainnya.

Berdasarkan analisis situasi diatas, permasalahan yang dihadapi mitra antara lain:

1. Permasalahan terkait dengan produksi

a. Minimnya pengetahuan, Teknologi dan Inovasi serta kreatifitas masyarakat dalam memanfaatkan bahan akar bambu menjadi PGPR.

b. Tingkat pendidikan formal, tingkat pendidikan sangat terkait dengan tingkat pengetahuan yang dimiliki oleh seseorang. Semakin tinggi tingkat pendidikan, maka semakin banyak pula pengetahuan yang dikuasainya. Semakin banyak pengetahuan, maka semakin mudah bagi seseorang untuk 
memahami berbagai informasi baru yang disampaikan. Berdasarkan informasi yang diperoleh dari Geuchik (Kepala Desa) dan kontak tani, pada umumnya petani di desa mitra berpendidikan rendah yaitu hanya tamatan Sekolah Dasar.

2. Permasalahan terkait dengan manajemen

a. Terbatasnya ketersediaan pupuk organik di Gampong Sarah Teubee, sementara bahan baku yang ada melimpah,

b. Terbatas nya pengetahuan petani dalam memanfaatkan sumberdaya lokal yang ada.

c. Belum memiliki jaringan pemasaran yang baik sehingga perlu diupayakan untuk dilakukan pengembangan jaringan pemasaran PGPR guna memberikan manfaat sehingga pendapatan petani menjadi meningkat.

\section{B. METODE}

Adapun tahapan atau langkah- langkah yang ditempuh guna melaksanakan solusi yang ditawarkan tersebut, secara rinci dapat dijelaskan sebagai berikut:

1. Penyediaan sarana produksi berupa bahan baku PGPR dan faktor pengetahuan tentang teknis budidaya. Penyediaan sarana produksi yang diberikan kepada mitra bertujuan membantu petani dalam penyediaan sarana produksi dan sebagai investasi modal awal bagi petani

2. Mendampingi petani pada saat pembuatan PGPR dengan memberikan sentuhan Teknologi dan Inovasi. Adapun langkah- langkah yang dilaksanakan dalam kegiatan ini yaitu:

a. Menjadwalkan pertemuan kelompok

b. Membuat jadwal sosialisasi teknis pembuatan PGPR

c. Membuat jadwal pelaksanaan pembuatan PGPR

d. Pendampingan kepada kelompok tani

e. Pelaksanakan evaluasi

3. Membuka dan memperluas jaringan pemasaran mitra

a. Mendorong Kelompok tani di Gampong Sarah Teubee agar dapat menjalin keria sama dalam bentuk mitra kerja bersama Dinas koperasi, perdagangan dan perindustrian Kabupaten Aceh Timur.

b. Mengajukan pembinaan pengembangan usaha dibidang perdagangan melalui Dinas koperasi, perdagangan dan perindustrian Kabupaten Aceh Timur.

Untuk mengukur tingkat keberhasilan kegiatan yang telah dilakukan, maka akan dilakukan evaluasi minimal 3 (tiga) kali, yaitu evaluasi persiapan, pelaksanaan, dan evaluasi tindak lanjut.

Pelaksanaan kegiatan pengabdian ini dilakukan selama 6 (enam) bulan yang didanai oleh DIPA Universitas Samudra. Adapaun jarak tempuh dari Universitas Samudra ke lokasi pengabdian adalah $30 \mathrm{KM}$, seperti yang ditunjukkan pada gambar 3 dibawah ini: 


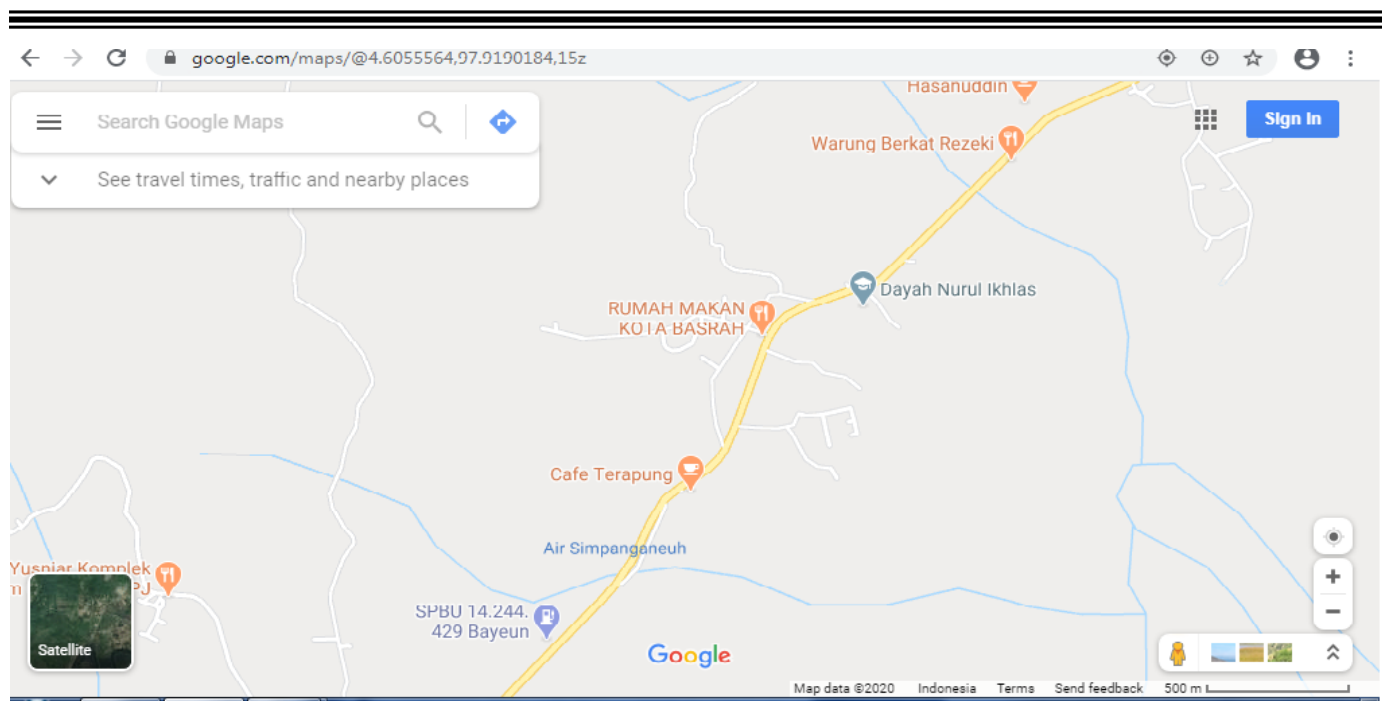

Gambar 3 Peta Lokasi Mitra Pengabdian

Adapun jadwal kegiatan yang pelaksanaan pengabdian kepada masyarakat di desa Sarah Teubee ini ditampilkan pada tabel 1 dibawah ini:

Tabel 1 Jadwal Kegiatan

\begin{tabular}{|c|c|c|c|c|c|c|c|}
\hline \multirow[t]{2}{*}{ No } & \multirow[t]{2}{*}{ Kegiatan } & \multicolumn{6}{|c|}{ Bulan } \\
\hline & & 4 & 5 & 6 & 7 & 8 & 9 \\
\hline 1 & Menjadwalkan pertemuan kelompok & & & & & & \\
\hline 2 & $\begin{array}{l}\text { Sosialisasi pelatihan PGPR kepada kelompok tani } \\
\text { dan resepresentatif aparatur Gampong }\end{array}$ & & & & & & \\
\hline 3 & Pelaksanaan pelatihan PGPR & & & & & & \\
\hline 4 & $\begin{array}{l}\text { Pendampingan kepada kelompok tani dalam teknis } \\
\text { pembuatan PGPR }\end{array}$ & & & & & & \\
\hline 5 & Pelaksanakan evaluasi pelatihan PGPR & & & & & & \\
\hline 6 & Pelaksanaan monitoring akses jaringan dan kemitraan & & & & & & \\
\hline 7 & Pelaksanaan rencana tindak lanjut & & & & & & \\
\hline
\end{tabular}

\section{HASIL ATAU PEMBAHASAN}

1. Kunjungan Ke Dinas Pemberdayaan Masyarakat dan Gampong Kabupaten Aceh Timur

Kegiatan ini dilakukan sebagai audiensi dan sosialisasi kegiatan pada dinas terkait sekaligus meminta dukungan atas pelaksanaan kegiatan pengabdian kepada masyarakat ini. Kunjungan tim pengabdian kepada masyarakat disambut langsung oleh sekretaris Dinas Pemberdayaan masyarakat dan Gampong dan didampingan oleh kepala bidang teknologi tepat guna kabupaten Aceh Timur. Dalam kesempatan ini pihak dinas sangat senang dengan diadakannya kegiatan pengabdian dengan tema pemberdayaan masyarakat melalui pelatihan pembuatan PGPR. Pihak dinas mengharapkan nantinya hasil pelatihan ini dapat memunculkan sebuah produk unggul khas gampong Sarah Teubee berupa PGPR yang sudah memiliki paten baik dari sisi produk maupun sisi penjualannya. Nantinya diharapkan produk PGPR ini dapat diikutkan dalam pameran tingkat 
propinsi sebagai hasil penerapan teknologi tepat guna sebagai hasil pembergayaan masyarakat dan gampong di desa Sarah Teubee.
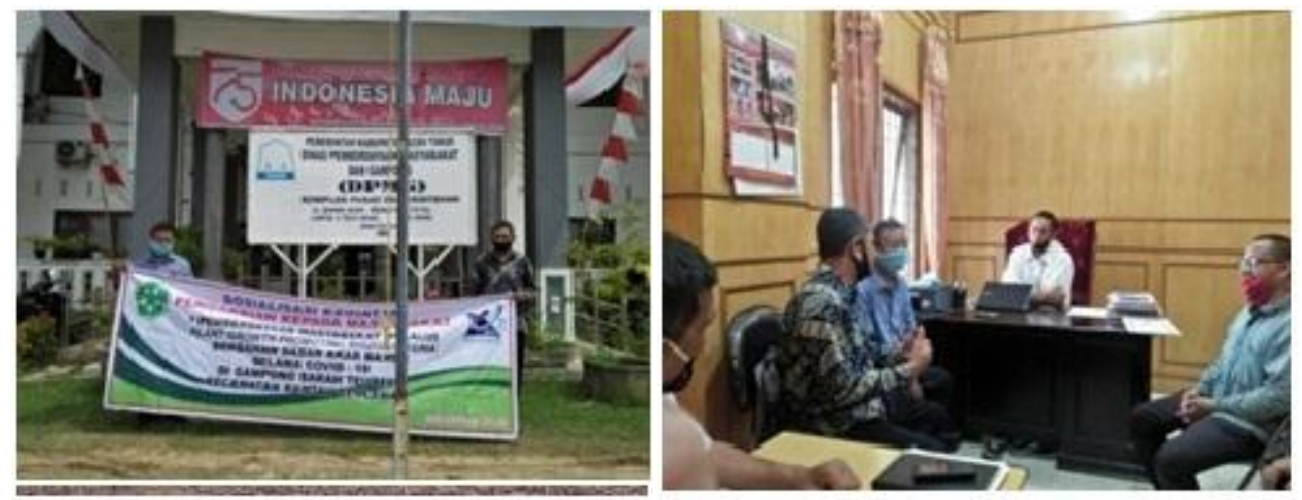

Gambar 4. Permohonan Izin pelaksaaan PKM

\section{Sosialisasi Kegiatan Kepada wanita Tani "Putroe Tani"}

Kegiatan ini dilakukan dalam rangka sosialisasi pelaksanaan PKM pada Pelatihan Pembuatan PGPR Berbahan Dasar Akar Bambu (Bambusa Sp) Di Desa Sarah Teubee Kecamatan Rantau Seulamat. Dalam kegiatan sosialisasi ini turut dihadiri oleh Bapak Geuchik Sarah Teubee yaitu Bapak Usmanuddin. Sosialisasi merupakan bagian dari kegiatan Pemberdayaan yang dilakukan di desa Sarah Teubee, dengan tujuan memberikan pemahaman akan pemanfaatan Sumber daya alam yang tersedia di desa, sehingga dapat memberikan nilai tambah dalam rangka menjalankan usaha pertanian masyarakat Desa sarah teubee khususnya dan masyarakat rantau selamat pada umumnya.
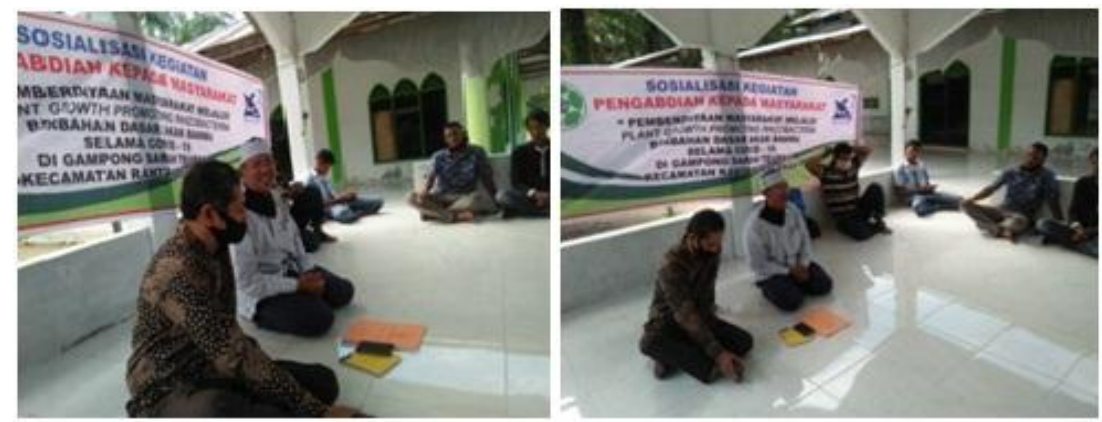

Gambar 5. Sosialisasi kegiatan PKM

\section{Pelatihan Pembuatan "Biang" Kepada Kelompok wanita Tani "Putroe Tani"}

Kegiatan ini dilakukan sebagai tindak lanjut hasil sosialisasi yang telah dilakukan pada tanggal 25 Juli 2020. Pada kesempatan ini tim PKM Unsam melakukan kegiatan berupa pengenalan bahan-bahan untuk pembuatan PGPR yang langsung disampaikan oleh narasumber yaitu Bapak. Anwar, SP. Adapun materi yang disampaikan dalam kegiatan ini meliputi ; Bahan-bahan yang diperlukan dan teknis pembuatan PGPR. Bahan Utama yang dibutuhkan : Akar bambu yang masih segar, Dedak, terasi, gula merah dan kapur sirih. Teknis pembuatannya; pertama sekali dengan menyiapkan biang dengan merebus air sampai matang, lalu didinginkan, kemudian dimasukkan air bersama akar bambu yang sudah 
terlebih dahulu disiapkan kedalam wadah (stoples) lalu difermentasi selama 5 hari.
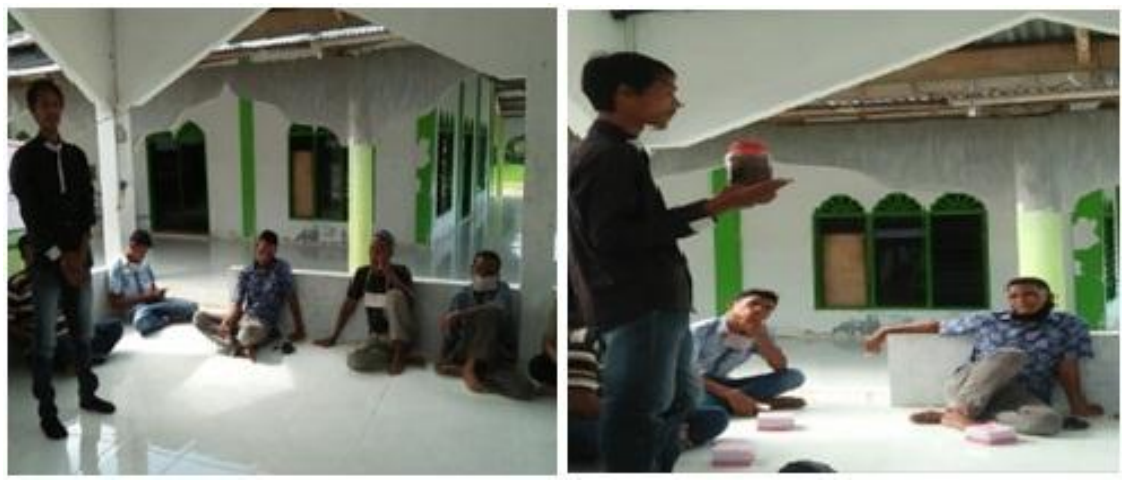

Gambar 6. Pelatihan Pembuatan "Biang" PGPR

\section{Pelatihan Pembuatan PGPR Kepada Kelompok wanita Tani "Putroe Tani"}

Setelah tim PKM Unsam melaksanakan tahap pengenalan bahan-bahan yang dibutuhkan untuk pembuatan PGPR, maka pada tanggal 8 Agustus 2020 tim PKM Unsam datang lagi kepada kelompok untuk mempraktekkan pembuatan PGPR yang diajarkan langsung oleh narasumber yaitu lbu Dedek. Teknis Pembuatan PGPR, dengan merebus air sebanyak 15 liter, bersamaan dedak, gula merah, kapur sirih dan terasi lalu dimasak sampai mendidih. Setelah itu air rebusan yang sudah dimasak bersama bahan dasar PGPR dibiarkan sampai dingin, lalu dituangkan kedalam drum plastik bersama dengan biang yang telah disiapkan. Selanjutnya ditutup rapat sampai kedap udara selama 7 hari dengan cara setiap hari drum plastik ini dibuka selama 5 menit lalu diaduk agar proses fermentasi itu berjalan dengan baik.


Gambar 7. Pelatihan Pembuatan PGPR

\section{Pembagian Hasil Pembuatan PGPR Kepada Kelompok wanita Tani "Putroe Tani"}

Kegiatan terakhir yang dilakukan oleh tim PKM Unsam adalah pelaksanaan pendampingan kepada kelompok wanita Tani "Putroe Tani" guna melihat hasil PGPR yang sudah dihasilkan beserta bibit cabai yang telah ditanam dalam polibeg yang menggunakan PGPR sebagai pupuk tanaman. Kegiatan ini juga 
didampingi oleh narasumber ibu Dedek. Dalam kesempatan ini Produk PGPR yang sudah jadi dan siapkan diaplikasikan sebanyak 1 drum plastik. PGPR juga diberikan kepada Kelompok untuk diaplikasikan di kebun praktek Kelompok Wanita Tani.


Gambar 8. Pembagian Hasil Pembuatan PGPR

\section{PENUTUP}

Dari hasil pengabdian kepada masyarakat yang telah dilaksanakan dapat kami tarik beberapa kesimpulan yaitu:

1. Kelompok wanita Tani telah memahami tatacara pembuatan PGPR berbahan dasar akar bambu (pupuk hayati),

2. Kelompok Wanita Tani, sudah mampu menghasilkan produk PGPR sendiri,

3. Kelompok Wanita Tani dapat memanfaatkan PGPR sebagai penambah unsur hara berbasis organik yang berfungsi menambah unsur hara tanaman dan menghemat penggunaan pupuk an-organik.

Adapun saran yang dapat kami sampaikan setelah pelaksanaan pengabdian kepada masyarakat ini adalah:

1. Pihak terkait diharapkan terus melakukan pendampingan guna semakin majunya usaha kelompok

2. Dibutuhkannya bantuan peralatan yang lebih layak bagi usaha kelompok

\section{E. UCAPAN TERIMA KASIH}

Tim pelaksana mengucapkan terima kasih kepada LPPM Universitas Samudra yang telah memberikan bantuan dana sehingga terlaksananya kegiatan ini. dan Tak lupa pula kami menyampaikan terima kasih kepada kelompok wanita Tani "Putroe Tani" yang telah menyempatkan waktu, tenaga dan pikiran untuk terlibat dalam kegiatan pengabdian kepada masyarakat tahun 2020.

\section{F. DAFTAR PUSTAKA.}

Ashrafuzzaman, M., F.A. Hossen, M.R. Ismail, Md.A. Hoque, M.Z. Islam, S.M. Shahidullah, and S. Meon. (2009). Efficiency of plant growth-promoting Rhizobacteria (PGPR) for the enhancement of rice growth. African .Journal of Biotechnology 8 (7): 1247-1252.

Desmawati. (2012). Pemanfaatan Plant Gworth Promoting Rhizobacteria (PGPR), Prospek dan Menjanjikan dalam Berusahatani Tanaman Hortikultura. 
http://Diltin.Holtikultura.go.id/tulisan/desmawati.htm.

Diakses

Pada Tanggal 4 September 2020.

Edi Husen et al, (2010). Pupuk Organik dan Pupuk Hayati,

Garcia, J.L., A. Probanza, B. Ramos, and F.J.G. Manero. (2001). Ecology, genetic diversity and screening strategies of plant growth promoting rhizobacteria. Journal of Plant Nutrition and Soil Sciences, 164: 1-7.

Indranada.H, K, (1986), Pengelolaan Kesuburan Tanah. PT. Bina Aksara Jakarta.

Kuntara, (2014). Cara Sederhana Membuat PGPR,

Marcia do Vale BF, et al, (2010) Plant Growth Promoting Rhizobacteria :

Fundamentals and Aplications by

Mader. P., F. Kaiser, A. Adholeya, R. Singh, H.S. Uppal, K. Anil. (2011). Inoculation of root microorganisms for sustainable wheat-rice and wheatblack gram rotations in India. Soil Biol Biochem.43:609-1

Nico Labuschagne et al. (2010). Plant Growth Promoting Rhizobacteria as Biocontrol Agents Against Soil-Borne Plant Diseases,

Rosliani, (2004). Pupuk Hayati. Penelitian Hortikultura, Bandung.

Sutanto, (2002). Peranan bahan organik terhadap kesuburan tanah dan upaya pengelolaannya. Dalam Pidato Pengukuhan Guru Besar. Universitas Sebelas Maret. Surakarta.

Stevenson,. F,. J., (1992). Humus Chemistry : Genesis, Composition, Reactoin. $2^{\text {nd }}$ ed. John Willey and Sons, New York.

Sutarwi., Pujiasmanto, B., Supriyadi, (2013). Pengaruh Dosis Pupuk Fosfat terhadap Pertumbuhan dan Hasil Beberapa Varietas Tanaman Kacang Tanah (Arachis hypogaea (L.) Merr) pada Sistem Agroforestri. J. El-Vivo, 1 (1): 42-48.

Sukamto, (2008). Membuat Pupuk Kompos Cair. PT. Agromedia Pustaka. Jakarta. 